Check for updates

Montreal

Cite this as: BMJ 2021;372:n281 http://dx.doi.org/10.1136/bmj.n281 Published: 29 January 2021

\title{
Covid-19: Countries are learning what others paid for vaccines
}

\section{Owen Dyer}

A string of revelations about vaccine prices has focused attention on a practice considered normal in the drug industry but often frowned on elsewhere: charging different prices to different customers for the same product.

South Africa's government found itself on the defensive this week after a senior health official revealed that 1.5 million doses of the Oxford and AstraZeneca vaccine just purchased for use among health workers would cost \$5.25 (£3.84; €4.32) a dose, more than twice what the European Union is paying at $\$ 2.15$.

The EU figure is known because Belgium's budget secretary inadvertently revealed the EU's negotiated prices for every major vaccine on Twitter last month. ${ }^{1}$ The EU had undertaken to keep the prices confidential in return for discounts.

South Africa's deputy director general of health, Anban Pillay, said his government had been told that $\$ 5.25$ was the set price for a country classified by the World Bank as upper-middle income. "The explanation we were given for why other high-income countries have a lower price is that they have invested in the [research and development], hence the discount," he added.

That principle has also been applied to the biggest players. The EU financially supported the development of the BioNTech and Pfizer vaccine and has obtained a lower price per dose $(\$ 14.70$ than the US (\$19.50). The Moderna vaccine's development was subsidised by the US government, and it will cost the US about $\$ 15$ a dose, while the EU is paying \$18.

The Oxford-AstraZeneca vaccine is much cheaper, although neither the UK nor the US can match the EU's \$2.15 deal: they are expecting to pay about \$3 and $\$ 4$, respectively, per dose.

The Johnson \& Johnson vaccine, expected to announce phase III results imminently, is also much cheaper, costing the EU \$8.50, with each dose going twice as far as the other brands, since it is a single shot vaccine.

AstraZeneca and Johnson \& Johnson have committed to not making a profit from the pandemic, while Moderna and Pfizer did not. AstraZeneca reserved the right, however, to declare the pandemic phase over and take profits from later vaccine sales.

Vaccine prices are only one factor in the cost of immunisation campaigns. Of the £11.7bn that the UK expects to spend on its vaccination programme, £2.9bn buys vaccines, securing 267 million doses of five different types, according to the National Audit Office. $^{2}$

Even the priciest vaccines repay their cost many times over in economic growth from a reopening economy.
Affluent governments could well be tempted to bid higher if supplies tighten.

Israel, which is on course to vaccinate all its citizens before any other country-having denied responsibility for vaccinating the Palestinians of the Occupied Territories-this month acknowledged paying \$23.50 per dose on average to Pfizer and Moderna to obtain early shipments. Even at this high price, vaccinating the entire population of Israel costs the economy only as much as two days of lockdown. Uniquely, Israel agreed to give Pfizer anonymised health data from all of its citizens as part of the deal.

\section{Africa secures doses}

For South Africa, more troubling than the high dose cost has been an inability to secure enough vaccine. The government planned to vaccinate 40 million of its 58.5 million people but has only enough vaccine on order for 10 million.

Covax, the World Health Organization's multilateral vaccine distribution programme, has set aside 600 million doses for Africa, enough to vaccinate a quarter of the continent's 1.2 billion population. But South Africa's status as an upper-middle income nation makes it ineligible for Covax assistance.

At a 26 January virtual meeting of the World Economic Forum, the country's president, Cyril Ramaphosa, called on rich nations to give up their surplus doses, noting that "some countries even acquired up to four times what their population needs."

On 28 January the African Union of 55 countries announced that it had secured 400 million extra doses of the Oxford-AstraZeneca vaccine, bringing its total order to 670 million. South Africa is likely to be a key beneficiary. Africa now has enough vaccine ordered to vaccinate half its population. The UK has ordered enough to theoretically vaccinate about three times its population.

Rich nations would reap huge economic benefits if they paid the roughly $\$ 27 \mathrm{bn}$ needed to fully fund the COVAX programme to vaccinate populations of developing nations, concluded a study commissioned by the International Chamber of Commerce Research Foundation. ${ }^{3}$ Failure to vaccinate those nations would cost the global economy up to $\$ 9.2$ trillion, the report found, with half of that cost falling on wealthy nations.

WHO's secretary general, Tedros Adhanom Ghebreyesus, commented, "I believe the world faces a catastrophic moral failure in equal access to the tools to combat the pandemic. This research shows a potentially catastrophic economic failure."

De Bleeker E. Deleted tweet showing EU vaccine prices. 17 Dec 2020. https://www.hln.be/binnenland/zoveel-gaan-we-betalen-voor-de-coronavaccins-staatssecretaris-zet-confidentiele-prijzen-per-ongeluk-online a3dceef4/180355293. 
2 National Audit Office. Investigation into preparations for potential COVID-19 vaccines. $14 \mathrm{Dec}$ 2020. https://www.nao.org.uk/wp-content/uploads/2020/12/Investigation-into-preparationsfor-potential-COVID-19-vaccines.pdf.

3 Çakmaklı CC, Demiralp S, Kalemli-Ozcan Ş, et al. The economic case for global vaccinations: an epidemiological model with international production networks. 25 Jan 2021. https://iccwbo.org/publication/the-economic-case-for-global-vaccinations.

This article is made freely available for use in accordance with BMJ's website terms and conditions for the duration of the covid-19 pandemic or until otherwise determined by BMJ. You may use, download and print the article for any lawful, non-commercial purpose (including text and data mining) provided that all copyright notices and trade marks are retained. 